\title{
Seasonal Variation of Quantitative Parameters of Coconut in Major Coconut Growing Districts of Andhra Pradesh, India
}

\author{
Kalpana Motha*, S. Vishala and Y. Ramakrishna \\ Horticultural Research Station, Dr. YSR Horticultural University, Vijayarai, \\ Andhra Pradesh, India \\ *Corresponding author
}

\begin{tabular}{|l|}
\hline Ke y w o r d s \\
Seasonal Variation, \\
Quantitative \\
Parameters, \\
Coconut \\
\hline Article Info \\
\hline $\begin{array}{l}\text { Accepted: } \\
\text { 17 July 2018 } \\
\text { Available Online: } \\
\text { 10 August } 2018\end{array}$ \\
\hline
\end{tabular}

\section{Introduction}

Coconut palm occupies a unique position in the socio- economic structure of the country. The coconut tree popularly called as "KalpaVrisha" is nature's gift to humanity and its fruit coconut is a valuable product. Nut, husk, shell, kernel, copra and oil derived from coconut are the important products that have in summer months.

\section{A B S T R A C T}

A study on "Seasonal variation in quantitative parameters of coconut in major coconut growing districts of Andhra Pradesh" was conducted during 2010-2012. The study revealed that the coconuts of Andhra Pradesh had an average whole nut weigh (1145.31 gm/nut), dehusked nut weight $(454.10 \mathrm{gm} / \mathrm{nut})$, husk weight $(686.76 \mathrm{gm} / \mathrm{nut})$, shell weight $(143.08 \mathrm{gm} / \mathrm{nut})$, water content $(92.75 \mathrm{ml} / \mathrm{nut})$ that were collected from three major coconut growing districts. The commercial valued products such as kernel, copra and coconut oil recorded an average of $215.57 \mathrm{gm} / \mathrm{nut}, 122.77 \mathrm{gm} / \mathrm{nut}$ and 65 percent respectively in the nuts of Andhra Pradesh. Among various seasons, the coconuts collected during winter months registered maximum whole nut weight $(1251.83 \mathrm{gm} / \mathrm{nut})$, husk weight $(811.40 \mathrm{gm} / \mathrm{nut})$ and shell weight $(149.47 \mathrm{gm} / \mathrm{nut})$ whereas the dehusked nut weight $(477.80 \mathrm{gm} / \mathrm{nut})$ and water content in mature nut $(98.60 \mathrm{ml} / \mathrm{nut})$ were maximum in summer collected nuts. Seasonal variation was also observed in commercial products viz., kernel weight, copra content and oil content in coconut of Andhra Pradesh that showed maximum kernel weight $(245.24 \mathrm{gm} / \mathrm{nut})$, copra content $(130.00 \mathrm{gm} / \mathrm{nut})$ and oil content (65.23 percent) in nuts harvested in summer months. In nutshell, the nuts of East Godavari district are good in size, husk weight, and oil content which can be exploited for coir making and oil production. The nuts of West Godavari district were good in copra that can be maximum utilized for making cup copra whereas the nuts of Srikakulam district was fairly good in kernel content which could be encouraged for desicatted coconut. Among different seasons, the best quality copra was obtained from 11th and 12th month old nuts 
productivity of 11,740 nuts/ha. Within the state, the coastal districts comprising East and West Godavari districts commands 50 percent of area under coconut in the state. In coastal ecosystem of Andhra Pradesh extending from Srikakulam to Nellore district, the coconut is cultivated under varied agro-climatic conditions. The predominant cultivar in the state was East Coast Tall. The quantitative and qualitative parameters of coconut depends upon various factors such as variety, age of the palm, soil, climate, maturity of nuts, season of harvest etc. Studies conducted at CPCRI, Kasarogod showed that the output of copra depends on the age of the nuts at the time of harvest and season of harvest. The quality and quantity of copra and oil in a mature coconut varies considerably from month to month within a year (Anonymous, 1988). Nambiar et al., 1969 stated that the nut development in coconut was likely to be effected by the season. The studies conducted at Coconut Research Station, Nileswar revealed that the copra content in a mature nut under West Coast condition was higher during the months from January to June and lower during the remaining months of the year. Various studies have been conducted at Central Plantation Crops Research Institute, Kasaragod on quantitative and qualitative parameters of coconut at different stages of growth revealed that the weight and thickness of the kernel and shell of the nut increses with decrease in nut water content whereas copra output was maximum in fully matured nuts (12th month old nuts). Naresh Kumar et al., (2006) reported that the fatty acid profile of a cultivar showed variation with the location, season and maturity of nut. But so far no current information is available on quantitative parameters of coconut in Andhra Pradesh with respect to season of harvest. Hence there is a need to evaluate the quantitative parameters of coconut in three major coconut growing areas of Andhra Pradesh in order to meet the demand of
International standards. Keeping in view, the present study was taken upon the quantitative parameters such as length and breadth of the fruit, whole nut weight, dehusked nut weight, husk weight, shell weight, copra and oil content in nuts of Andhra Pradesh in various seasons.

\section{Materials and Methods}

Survey was conducted in three major coconut growing districts (East Godavari, West Godavari and Srikakulam) of Andhra Pradesh (having share of $81 \%$ area under coconut in Andhra Pradesh) during June, 2010 to May, 2012. A total of six palms per holding were randomly chosen for collection of nuts from predominant variety i.e., East Coast Tall. From each holding 72 nuts of 10 th, 11 th \& 12th month old nuts (12 nuts of each) were collected from tagged bunches in three seasons viz., winter (November-February), summer (March-June), rainy (July-October) and transported to Horticultural Research Station, Ambajipeta to study the quality parameters viz., whole nut weight, dehusked nut weight, husk weight, shell weight, meat weight, water content, copra content and oil content. The nuts of age groups viz. 10th, 11th, 12th month old collected in different seasons were subjected to collection of data manually (Plate-1). The length and breadth of the fruit were measured by scale and the data was recorded in centimeters. Then the nuts were weighed as a whole to record the whole nut weight, and the nuts were dehusked by coconut dehusker or manually by crow bar. The husk weight and dehusked nut weight were recorded separately on weighting balance of $5 \mathrm{~kg}$ capacity. Further, the nuts were split opened and the water content in the nut was collected in the measuring cyclinder and recorded the water content in $\mathrm{ml}$. The split opened nuts were generally sun dried but during rainy days and cloudy weather the nuts were dried in shell fired copra drier. After two 
days the kernel was separated from the shell and it was again dried either in sun or shell fired copra drier till the moisture level in the copra reaches to six percent to obtain better quality copra (Plate-2). Then the weight of the shell and copra content were weighed and recorded the observations. The observation on quantitative parameters viz., length and breadth of the fruit, whole nut weight, dehusked nut weight, husk weight, shell weight, water content, kernel weight, copra content and oil content were pooled in each season and presented in tables and figures.

\section{Results and Discussion}

\section{Quantitative parameters of coconut in Andhra Pradesh}

Survey conducted in the three major coconut growing districts of Andhra Pradesh on study of quantitative parameters of coconut (Table 1) revealed that the length and breadth of the fruit ranged from 19.83 to $21.00 \mathrm{cms}$ and 13.79 to $14.15 \mathrm{~cm}$ respectively. The whole nut weight in the state ranged from 1126.96 to $1172.01 \mathrm{gm} / \mathrm{nut}$, dehusked nut weight ranged from 443.93 to $462.22 \mathrm{gm} / \mathrm{nut}$, husk weight of 667.64 to $717.07 \mathrm{gm} / \mathrm{nut}$, water content ranged from 87.45 to $98.02 \mathrm{ml} /$ nut and shell weight ranged from 133.34 to $160.78 \mathrm{gm} /$ nut with an average of $1145.31 \mathrm{gm} / \mathrm{nut}, 454.10 \mathrm{gm} / \mathrm{nut}$, $686.76 \mathrm{gm} / \mathrm{nut}, 92.75 \mathrm{ml} / \mathrm{nut}$ and 143.08 $\mathrm{gm} / \mathrm{nut}$ respectively. Maximum whole nut weight (1172.01 gm/nut), husk weight (717.07 $\mathrm{gm} / \mathrm{nut}$ ) and shell weight (160.78 gm/nut) were recorded in the nuts collected from East Godavari district whereas dehusked nut (462.22gm/nut) and water content (98.02 $\mathrm{ml} / \mathrm{nut}$ ) were maximum in collected from Srikakaulam district.

The quantitative parameters of coconut viz., kernel weight, copra content and oil percentage of coconut in different districts of Andhra Pradesh were presented in Figure 1 showed that the kernel weight ranged from 207.02 to $226.76 \mathrm{gm} /$ nut with an average of $215.57 \mathrm{gm} / \mathrm{nut}$ in the state and maximum weight of the kernel (226.75 gm/nut) was recorded in the nuts of Srikakulam district and minimum kernel weight (207.92 gm/nut) was recorded in nuts collected from East Godavari district.

The copra content (gm/nut) in the state ranged from 115.90 to $128.56 \mathrm{gm} / \mathrm{nut}$ with an average of $122.77 \mathrm{gm} /$ nut and oil percentage in the nut ranged from 62.64 to $65.00 \%$ with an mean of 64 percent of oil in the nuts of coconut in Andhra Pradesh. Among the three districts, the nuts collected from West Godavari district showed the highest copra content/nut(128.15 $\mathrm{gm} / \mathrm{nut}$ ) and minimum in Srikakulam district (115.90 gm/nut) and maximum oil percent $(65 \%)$ was recorded in nuts of East Godavari district and minimum oil percent $(62.64 \%)$ in nuts of Srikakulam district.

It is observed from the Table 2, that the length and breadth of the fruit $(21.16 \& 14.49 \mathrm{cms})$, whole nut weight (1251.83 gm/nut), husk weight (811.40 gm/nut), shell weight (149.47 $\mathrm{gm} / \mathrm{nut}$ ) were maximum in nuts harvested during winter months whereas dehusked nut weight (477.80 gm/nut) and water content (98.60 $\mathrm{ml} / \mathrm{nut})$ were maximum in nuts harvested during summer season. Minimum values of length and breadth of the fruit (19.55 \&13.73 cms), whole nut weight (1067.98 gm/nut), husk weight (590.17gm/nut) were recorded in nuts harvested during summer months of the year.

The lowest values of quantitative parameters viz., length \& breadth of the fruit, whole nut weight and husk weight during summer months harvested nuts were attributed due to the reason that the palm produces more number of nuts in summer months, hence the size of the nuts was reduced resulting in minimum values of observations on 
quantitative parameters viz., length \& breadth of the fruit, whole nut weight, husk weight etc.

The data on variation of quantitative parameters viz., weight of the kernel, copra content and oil percentage with respect to the season of the harvest of nuts or maturity of nuts in various seasons were given in figures. It was noticed from the Figure 2, that the highest weight of the kernel (245.24 gm/nut), copra content (130.00 gm/nut) and oil percentage in the nuts $(65.23 \%)$ were observed in nuts harvested in the months of summer season and minimum values of kernel weight (189.55 gm/nut), copra content (114.81gm/nut) and oil percentage in nuts $(62.32 \%)$ were observed in the nuts harvested or matured during winter months.

Quantitative parameters of coconut in various seasons in different districts of Andhra Pradesh

The quantitative parameters of coconut viz., length and breadth of the fruit, whole nut weight, dehusked nut weight, husk weight, water content and shell weight in various seasons in three major coconut growing districts of Andhra Pradesh was presented in the Table 3. The length and breadth of the fruit in various seasons in three major coconut growing districts ranged from 18.78 to 21.75 cms and 13.38 to $14.71 \mathrm{cms}$ respectively. The highest length and breadth of the fruit $(21.75$ \& $14.71 \mathrm{cms}$ ) were recorded in nuts collected from East Godavari district during winter months

Table.1 Quantitative parameters of coconut in three different districts of Andhra Pradesh

\begin{tabular}{|l|c|c|c|c|}
\hline Quantitative Parameters & $\begin{array}{l}\text { East Godavari } \\
\text { District }\end{array}$ & $\begin{array}{l}\text { West Godavari } \\
\text { District }\end{array}$ & $\begin{array}{l}\text { Srikakulam } \\
\text { District }\end{array}$ & Mean \\
\hline Length of the fruit (cms) & 21.00 & 19.83 & 20.50 & 20.44 \\
\hline Breadth of the fruit (cms) & 14.15 & 13.79 & 14.12 & 14.02 \\
\hline Whole nut weight(g/nut) & 1172.01 & 1126.96 & 1136.95 & 1145.31 \\
\hline Dehusked nut weight (g/nut) & 456.14 & 443.93 & 462.22 & 454.10 \\
\hline Husk weight (g/nut) & 717.07 & 675.58 & 667.64 & 686.76 \\
\hline Water content (ml/nut) & 87.45 & 92.76 & 98.03 & 92.75 \\
\hline Shell weight (g/nut) & 160.78 & 133.34 & 135.12 & 143.08 \\
\hline
\end{tabular}

Table.2 Quantitative parameters of coconut in different Seasons in Andhra Pradesh

\begin{tabular}{|l|c|c|c|}
\hline Quantitative Parameters & \multicolumn{3}{|c|}{ Seasons } \\
\hline Length of the fruit (cms) & Winter & Summer & Rainy \\
\hline Breadth of the fruit (cms) & 14.16 & 19.55 & 20.62 \\
\hline Whole nut weight(g/nut) & 1251.83 & 1067.98 & 13.84 \\
\hline Dehusked nut wt (g/nut) & 431.28 & 477.80 & 1116.11 \\
\hline Husk weight (g/nut) & 811.40 & 590.17 & 453.21 \\
\hline Water content (ml/nut) & 89.63 & 98.60 & 658.73 \\
\hline Shell weight (g/nut) & 149.47 & 141.16 & 95.03 \\
\hline
\end{tabular}


Table.3 Seasonal variation in quantitative parameters of coconut in different districts of Andhra Pradesh

\begin{tabular}{|c|c|c|c|c|c|c|c|c|c|}
\hline \multirow[t]{2}{*}{ Quantitative Parameters } & \multicolumn{3}{|c|}{ East Godavari District } & \multicolumn{3}{|c|}{ West Godavari District } & \multicolumn{3}{|c|}{ Srikakulam District } \\
\hline & Winter & Summer & Rainy & Winter & Summer & Rainy & Winter & Summer & Rainy \\
\hline Length of the fruit(cms) & 21.75 & 19.84 & 21.42 & 20.73 & 18.78 & 19.99 & 21.00 & 20.04 & 20.45 \\
\hline Breadth of the fruit(cms) & 14.71 & 13.78 & 13.96 & 14.53 & 13.38 & 13.46 & 14.23 & 14.04 & 14.09 \\
\hline Whole nut weight(g/nut) & 1265.57 & 1095.32 & 1155.14 & 1241.00 & 1030.01 & 1109.87 & 1248.90 & 1078.61 & 1083.32 \\
\hline Dehusked nut wt(g/nut) & 421.62 & 490.80 & 456.00 & 420.57 & 469.25 & 441.98 & 451.65 & 473.36 & 461.65 \\
\hline Husk weight(g/nut) & 843.95 & 604.52 & 702.76 & 814.25 & 560.76 & 651.75 & 776.01 & 605.24 & 621.67 \\
\hline Water content(ml/nut) & 81.36 & 92.63 & 88.38 & 89.53 & 92.84 & 95.93 & 98.00 & 95.32 & 100.76 \\
\hline Shell weight(g/nut) & 157.55 & 172.72 & 152.07 & 141.27 & 124.80 & 133.67 & 150.00 & 125.94 & 129.82 \\
\hline
\end{tabular}


Plate.1 Methodology followed in collection of nuts

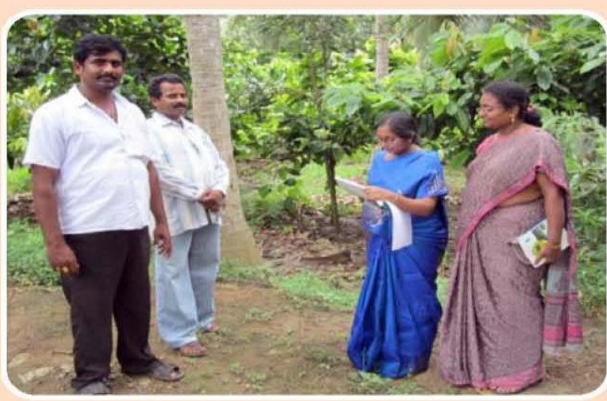

Collection data from farmer

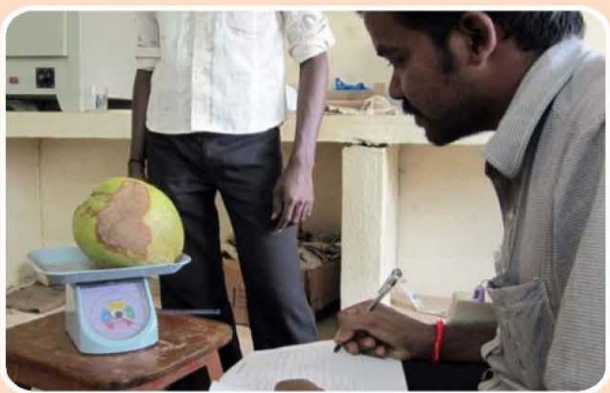

Recording data on whole nut weight

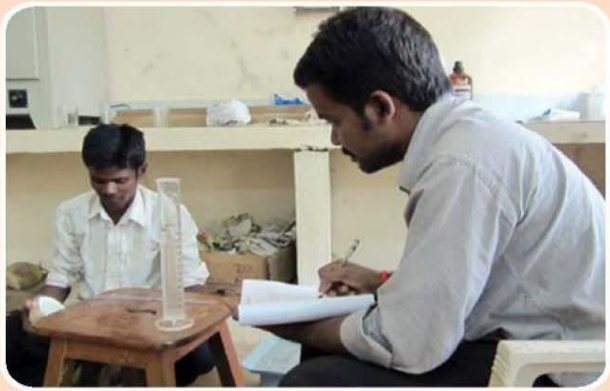

Measuring of water content in mature nuts

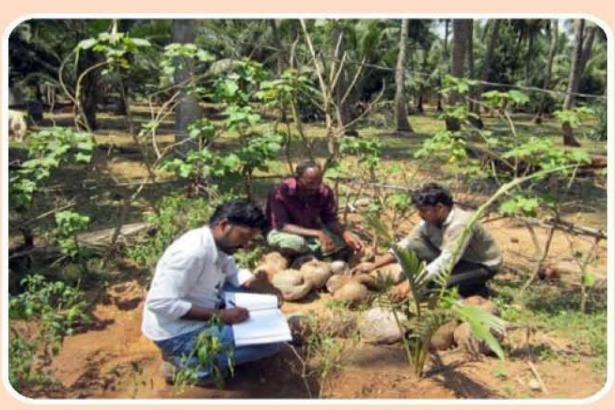

Collection of nuts from the field

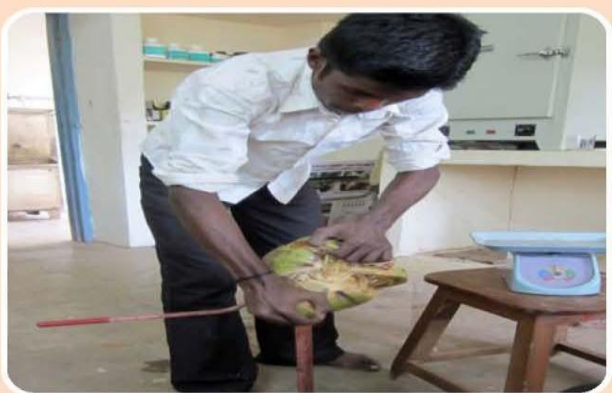

Dehusking of nut

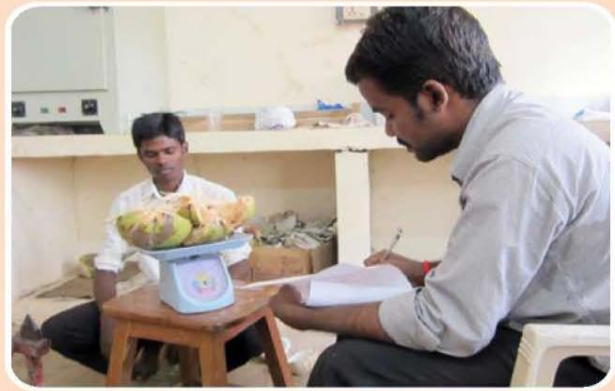

Recording data on husk weight

Plate.2 Method of drying of copra and moisture estimation in copra samples

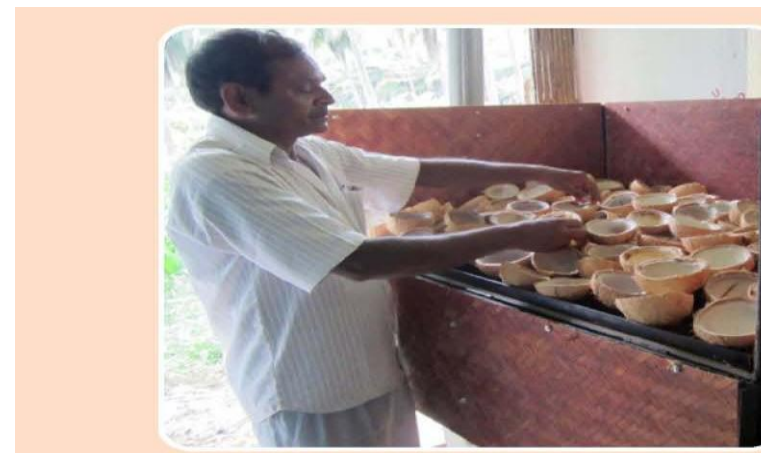

Drying of copra in shell fired copra drier

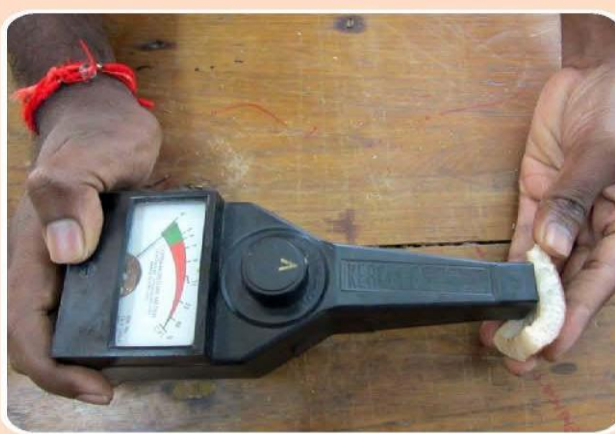

Observing moisture content with moisture meter 
Fig.1 Quantitative parameters of kernel, copra and oil in coconut in different districts of Andhra Pradesh

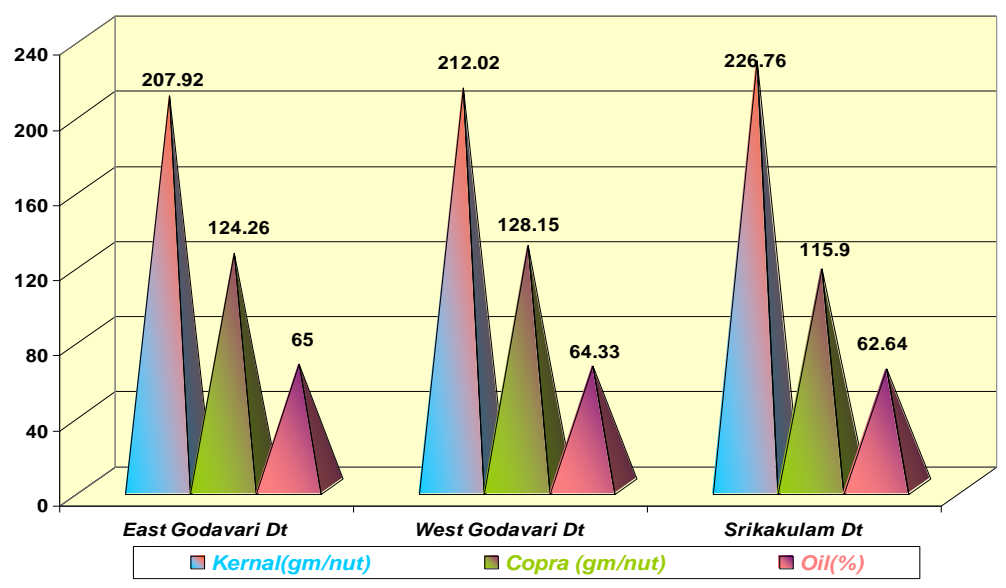

Fig.2 Kernal, copra and oil content of coconut in different seasons in Andhra Pradesh

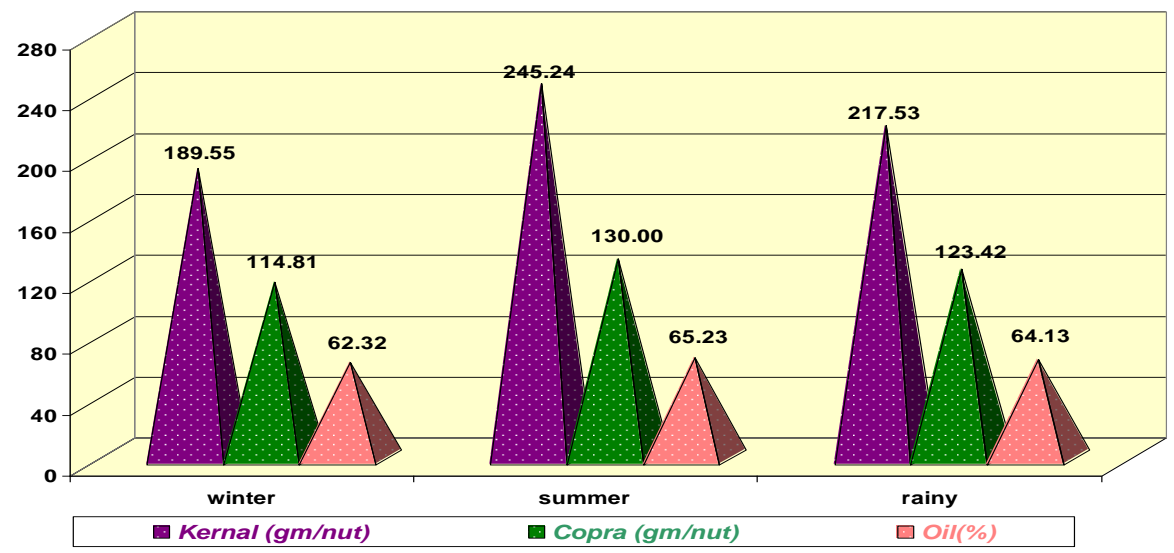

Fig.3 Seasonal variation of Kernal weight of coconut in different districts of Andhra Pradesh

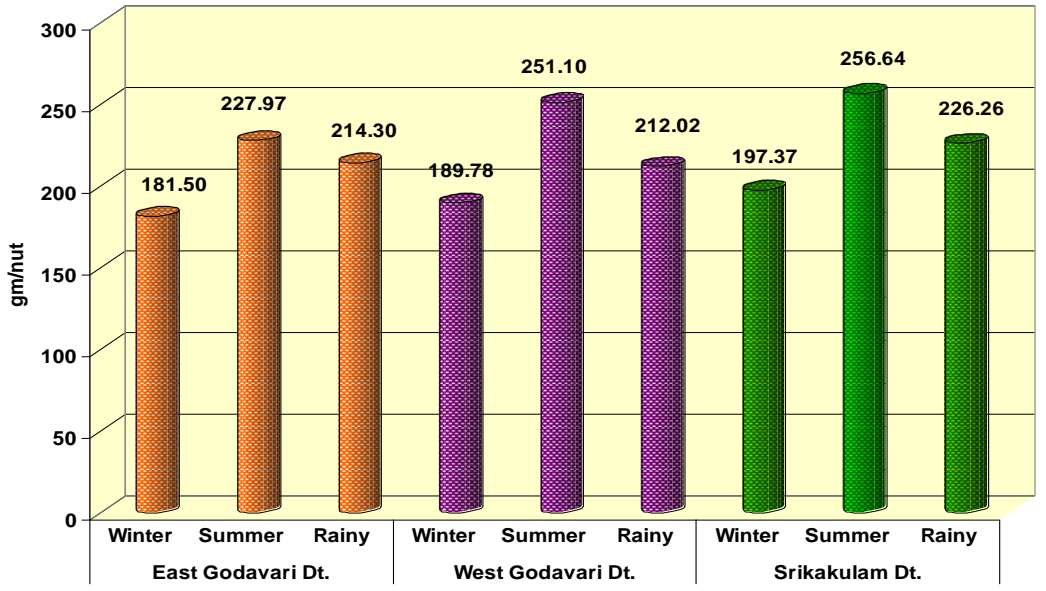


Fig.4 Seasonal variation of Copra content of coconut in different districts of Andhra Pradesh

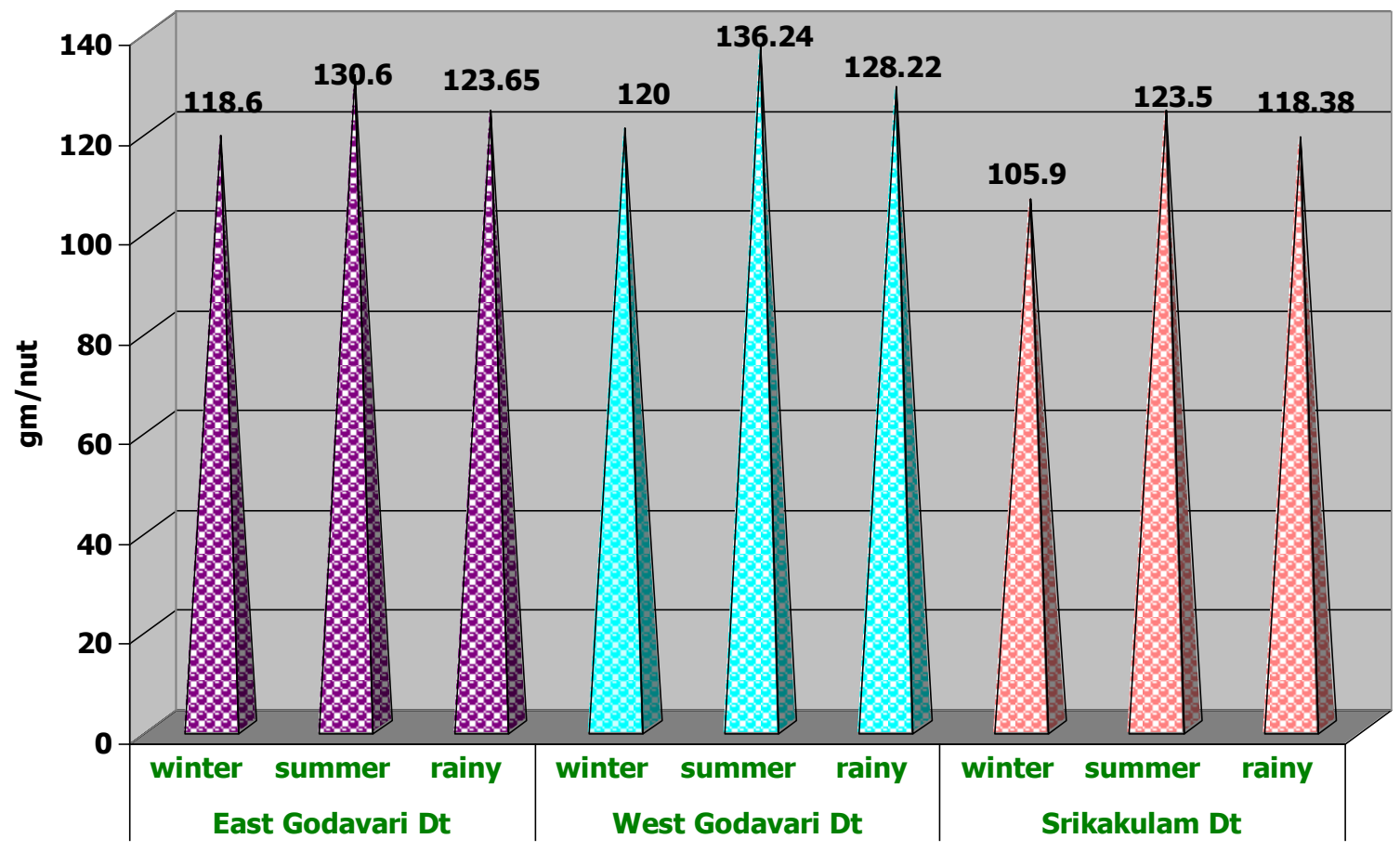

Fig.5 Seasonal variation of oil content of coconut in different districts of Andhra Pradesh

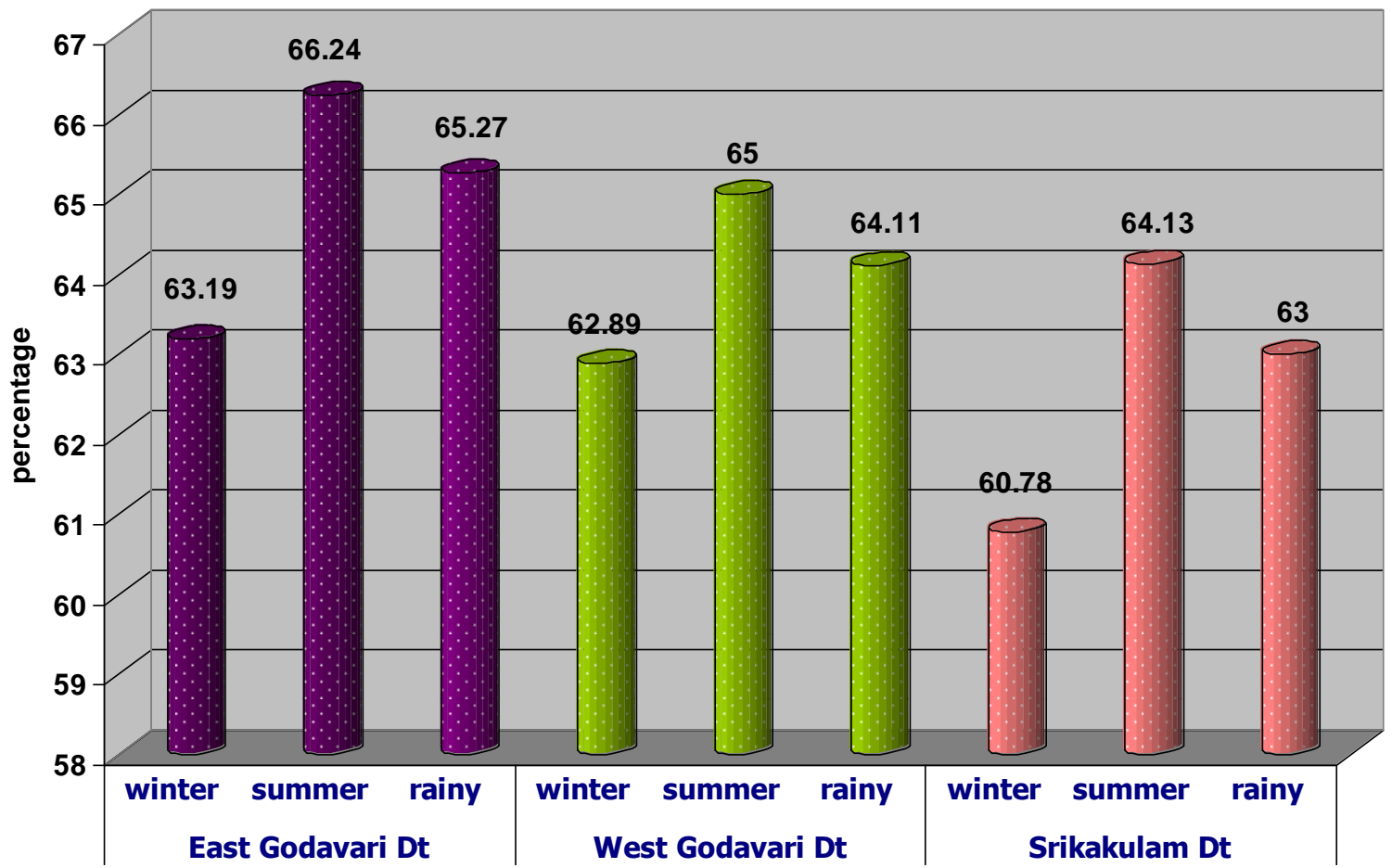


The Whole nut weight ranged from 1030.01 to $1265.67 \mathrm{gm} /$ nut, dehusked nut weight from 420.57 to $490.80 \mathrm{gm} /$ nut, husk weight ranged from 560.76 to $843.95 \mathrm{gm} /$ nut, water content ranged from 81.36 to $100.76 \mathrm{ml} / \mathrm{nut}$ and weight of the shell ranged from 124.80 to $172.72 \mathrm{gm} / \mathrm{nut}$ in various seasons in major coconut growing districts.

Maximum whole nut weight of 1248.91 $\mathrm{gm} /$ nut and $1247.96 \mathrm{gm} / \mathrm{nut}$ and husk weight of $843.95 \& 776.01 \mathrm{gm} /$ nut were recorded in nuts collected from Srikakulam and East Godavari districts harvested during winter months whereas maximum dehusked nut weight of $490.80 \& 473.37 \mathrm{gm} / \mathrm{nut}$ recorded in nuts collected from West Godavari and Srikakulam districts during summer months. The weight of the shell (172.72 gm/nut) was maximum in nuts harvested in summer months collected from East Godavari district of Andhra Pradesh.

The observation on quantitative parameters $v i z$. , weight of the kernel, copra content and oil percentage in nuts showed variation with respect to season of maturity or harvest of nuts in various season in three major coconut growing districts of Andhra Pradesh. The weight of the kernel in various seasons in different districts of Andhra Pradesh (Fig. 3) ranged from 181.50 to $256.64 \mathrm{gm} /$ nut with maximum kernel weight (256.64 gm/nut) recorded in nuts collected from Srikakulam district followed by the nuts from West Godavari district (251.10 gm/nut) during summer months whereas minimum kernel weight (181.50 gm/nut) was observed in nuts collected from East Godavari district during winter months. It was observed from the Figure 4, that the copra content in various in different districts ranged from 105.90 to $136.24 \mathrm{gm} /$ nut with maximum copra content of $136.24 \mathrm{gm} /$ nut \& $130.60 \mathrm{gm} /$ nut in nuts harvested during summer months collected from West Godavari district \& East Godavari districts respectively and minimum copra content (105.90 gm/nut) in nuts collected from Srikakulam district during winter months.

The quantitative parameters of coconut vary with region and also season. The highest nut weight, husked nut weight, shell weight were observed in the nuts of the East Godavari district whereas maximum dehusked nut weight and water content in mature nut were noticed in the nuts of Srikakulam district. The nuts of Srikakulam is good in kernel weight, West Godavari district is good in copra content while the nuts of Wast Godavari is good in oil content. Similar findings were reported in oilpalm where an appreciable difference was noticed in oil to bunch percentage grown in different regions, with a higher value in the wettest climate, compared to the value in two other regions (Prabowo et al., 2002). Seasonal variation was observed generally in various oil producing crop. Variation in the size of the nuts, husk, kernel, copra and oil in coconut is affected by the season of harvest. Maximum whole nut weight, husk weight and shell weight was noticed in the nuts harvested in the months of winter season whereas the dehusked nut weight and water content were highest in nuts harvested during summer season. The lowest values of quantitative parameters viz., length $\&$ breadth of the fruit, whole nut weight and husk weight during summer months harvested nuts were attributed due to the reason that the palm produces more number of nuts in summer months. The highest weight of the kernel, copra content, and oil percentage were observed in nuts harvested in the months of summer season and minimum values of kernel weight, copra content and oil percentage in nuts were observed in the nuts harvested or matured during winter months. The results were in tune with the findings of different authors in various oil producing crops viz., oil palm, olive etc. where 
harvesting times affect oil content and fatty acid composition. Nambiar et al., (1969) observed that the final nut weight and weight of unhusked nut and copra content in nuts is highly correlated with growth during second phase and also the weather condition of the region. Also reported that a negative relationship between heat units (which is a function of temperature) during the second phase of development (4-7 months after fertilization) and husked nut weight. Nambiar and Rao (1991) reported that the copra content of fruits is maximum during summer followed by winter and minimal in the postmonsoon period of October-November. Louis and Ramachandran, 1981 opined that oil content in copra and oil yield per hectare varies with cultivar and also season and reported that the nuts harvested during the June-July months had highest percentage of oil (Naresh Kumar et al., 2000) (Fig. 5).

The reason may be that the number of dry days and sunshine hours are the factors responsible for the variation in percentage of copra to nut and oil to copra (Akpan and Obisesan, 1984). Mhanhmad et al., 2011 observed that the bunch components in oil palm showed significant difference between seasons. Percent wt/wt of fruits/bunch and kernels/bunch harvested in dry season were higher than those in wet season. Similarly, the mesocarp and kernel oil to bunch ratio of the dry season samples were higher than those in wet season. This may be due to effect of solar radiation on oil synthesis.

Andhra Pradesh is one of the major coconut growing states of India with maximum productivity of 11,740 nuts/ha. The present survey in major coconut growing districts revealed that the nuts of East Godavari district are good in size, husk weight, and oil content which can be exploited for coir making and oil production. The nuts of West Godavari district were good in copra that can be maximum utilized for making cup copra whereas the nuts of Srikakulam district was fairly good in kernel content which could be encouraged for desicatted coconut. Among different seasons, the best quality copra was obtained from 11th and 12th month old nuts in summer months. This information on quantitative aspects of coconut products of various districts of Andhra Pradesh provides farmer for better possible exploitation of their products and biproducts of coconut.

\section{Acknowledgments}

The authors greatly thankful to to Coconut Development Board, Kochi for financial assistance, Honourable Vice Chancellor and Dr. YSR Horticultural University, Venkataramannagude for providing infrastructural facilities to carry out the project work and sectioning administrative provisions relating to the project work.

\section{References}

Akpan, E.E.J. and I.Q. Obisesan. 1984. The effect of climate factors upon nut characteristics of the coconut palm (Cocosnu cifera L.). In: Cocoa and Coconuts; Progress and outlook. (Eds.) S. Pushparajah, and Chew Poh Soon. Incorporated society of Planters, Kula Lumpur (Malaysia), pp. 733-744.

Anonymous, 1988. Annual Report 1987-88. Central Plantation Crops Research Institute, Kasaragod, India, pp. 43-45.

Louis, I.H. and Ramachandran T.K., 1981. Note on the oil content of some varieties of coconut palm. Indian Coconut Journal. 12: 4-5.

Mhanhmad, S., Leewanich P., Punsuvon V., Chanprame S. and Srinives P. 2011. Seasonal effects on bunch components and fatty acid composition in Dura oil palm (Elaeisguine ensis). African 
Journal of Agricultural Research Vol. 6(7), pp. 1835-1843.

Nambiar, M.C., Sreedharan, A., Sankar, N. 1969. Preliminary observations on growth pattern and the likely effect of seasons on nut development on coconut. Journal of Agricultural Sciences.39:455-461.

Nambiar, N.P.K. and Rao, G.S.L.H.V.P. 1991. Varietal and seasonal variation in oil content of coconut. Coconut Breeding and Management (eds. Silas, E.G. Aravindakshan, M. and Jose, A.I.). Proceedings of National Symposium on Coconut Breeding and Management, 1988. Kerala Agricultural University, Thrissur, pp. 283-286.
Naresh Kumar, S., Balakrishnan, A. and Rajagopal, V. 2006. Fatty acids in coconut oil. Indian Coconut Journal. 37(5), 4-14.

Naresh Kumar, S., Champakam, B. and Rajagopal, V. 2000. Fatty acid composition of coconut oil among the cultivars - An insight into industrial application. Indian Coconut Journal. 31:25-28.

Prabowo N.E., Foster, H.L, Subagio A (2002). Variation in oil and kernel extraction rates of oil palm with environment in North Sumatra. Paper presented at 2002 Int. Oil Palm Conf., Indonesian Oil Palm Res. Inst., Bali, 812 July.

\section{How to cite this article:}

Kalpana Motha, S. Vishala and Ramakrishna, Y. 2018. Seasonal Variation of Quantitative Parameters of Coconut in Major Coconut Growing Districts of Andhra Pradesh. Int.J.Curr.Microbiol.App.Sci. 7(08): 3086-3096. doi: https://doi.org/10.20546/ijcmas.2018.708.329 